Gadjah Mada International Journal of Business

September 2002, Vol. 4, No. 3, pp. 297-313

\title{
DOES SIZE MATTER? Technical Efficiency and Industry Size in Indonesia
}

\author{
Richard V. Llewelyn \\ Wang Sutrisno
}

The debate over which size industry is best suited for Indonesia continues with proponents of both large and small sizes pointing out the benefits of each. However, little empirical analysis has been done regarding economic matters such as technical efficiency.

Nonparametric analysis of technical efficiency for three sizes of firms in seven manufacturing sectors is estimated using linear programming techniques. Aggregated input and output data from BPS from 1991 to 1997 are used.

Household size firms are found to be most efficient relative to the other sizes for five of the seven sectors analyzed. Large firms are relatively more efficient in 'Food, Beverage, and Tobacco' sector. Small companies are relatively less efficient than household firms in all but one case, but relatively more efficient than large firms infive of seven sectors. The results validate and perhaps explain the duel economy in Indonesia with both large and small firms existing in the same industry.

When each sector is analyzed for each firm size, the 'Non-Metallic Mineral Products Other Than Petroleum and Coal' sector is most efficient for all sizes offirms. The least efficient sector is the 'Chemical and Plastics' industry.

The results suggest that government policy should be focused on creating a stable environment for business, which promotes growth of efficient businesses, either large or small. Specific policies and intervention for small business development are not necessary, given the relative efficiency of small firms in Indonesia.

Keywords: firm size; manufacturing sector; non-parametric; technical efficiency 


\section{Introduction}

Rhetoric often obscures the truth, particularly in the political realm. The merits of large versus small industries in Indonesia are frequently debated, often in public seminars as well as the mass media in Indonesia. However, little of the debate has involved empirical analysis but rather is founded on a priori conceptions and perceptions. Often, objective and empirical issues such as efficiency are clouded by more subjective issues such as equity, making the discussion less clear.

Is it indeed true that one of the causes of the economic crisis was due to large corporations receiving special benefits and incentives from previous governments and that these large industries are inefficient and the government should use policies, which encourage development of small industries in developing the economy because they are more efficient? Or, are large firms able to achieve economies of scale and scope that cannot possibly be achieved by smaller firms, making the larger firms more efficient and thus necessary for economic recovery and development? These questions can be empirically evaluated, whereas the case that small businesses should be supported and given special incentives in order to bring about greater equity is more subjective and more difficult to evaluate.

The government headed by President Habibie from 1998-1999 developed several policies specifically designed to assist small businesses and cooperatives. Minister of Cooperatives, Adi Sasono, was particularly critical of large companies and their (perceived) role in the economic crisis. During the administration of President Abdurahman Wahid, the debate was more muted. However, this issue has received renewed interest recently following the installation of President Megawati, who is generally viewed to be more populist in nature than President Wahid. Amien Rais, the head of the People's Consultative Assembly (Majelis Permusyawaratan Rakyat or MPR), has criticized the government, suggesting that policy continues to favor large corporations instead of small business and should be changed, with direct assistance going to small business (Jakarta Post 2001).

Empirical research comparing the economic performance of large versus small companies is quite limited for Indonesia. Much of the debate regarding large versus small industry involves anecdotal "evidence" and a priori suppositions by both sides, both in the government and in the academic realm. As Hill (1999) noted, though there are no reliable data on the impact of the crisis on different sized enterprises, anecdotal evidence seems to suggest that small businesses have done better during the crisis than larger firms, due perhaps to being less exposed to the financial sector, in addition to being linked to the agriculture sector. However, as he noted, this would suggest that specific short-term policies aimed at aiding small businesses are less necessary than if they were doing poorly.

This research evaluates relative technical efficiency for large, small, and household (cottage) industries in seven specific sectors from 1991-1997, before the economic crisis. If, as critics suggest, poor performance by large companies contributed to the crisis, it may be hypothesized that in the period leading up to the crisis larger firms would indeed be less efficient in use of resources, measured by technical efficiency. It should be noted that factors other than technical inefficiency in the manufacturing sector, including high levels of debt and speculative investments, may have contributed to poor 
performance by large firms. However, this analysis is limited to evaluating technical efficiency, to determine if from an efficiency standpoint, large companies are more or less efficient than small companies. Since different production sectors behave differently, the analysis is done by sector to allow for sectoral differences in efficiency.

\section{Efficiency and Related Literature}

Technical efficiency is analyzed using nonparametric analysis involving linear programming. This technique has been used for a variety of analyses of technical efficiency (Grabowski and Pasurka 1987; Featherstone et al. 1997) including in Indonesia (Llewelyn 1997).

Technical efficiency may be defined as the ability to produce as much output as possible with a specified level of inputs, given the existing technology. Technical inefficiency occurs when a firm fails to operate on the production frontier (Byerlee 1987). The concept of the efficient frontier often has often been used to measure technical efficiency, where deviations from the frontier are assumed to represent inefficiencies. Analysis of frontier efficiency varies a great deal with the major differences related to the assumptions on the outer bound of the frontier, which may be deterministic or stochastic, and to the method of measurement, parametric or nonparametric.

Nonparametric efficiency analysis has the advantage of imposing no $a$ priori parametric restrictions on the underlying technology, because it does not require a specific functional form for the frontier to be specified. Therefore, it does not impose unwarranted structure on the technology that might create a distortion in the effi- ciency measures (Färe et al. 1985). Also, it can handle both disaggregated inputs and multiple output technologies as well as highly aggregated inputs.

This study uses nonparametric techniques to evaluate technical efficiency of different industries size in several industrial sub-sectors in Indonesia. A nonparametric frontier is estimated for each year of the study for three sizes of industry, large, small, and household, with relative overall technical efficiency being determined for each industry size annually for each sub-sector. The seven sub-sectors analyzed are food, beverages, and tobacco; textiles, clothing, and leather; wood products and furniture; paper, printing and publishing; chemicals and plastics; nonmetallic mineral products other than petroleum and coal; and finally fabricated metal products, machinery and equipment. Analysis is conducted at the industry level using aggregated data from the Central Bureau of Statistics (BPS) for various years, though if data were available, the same methodology could be used with firm-level data.

Most analysis of technical efficiency in economic literature generally deals with relative efficiency of firms. Micro-level studies such as these have been conducted in the agricultural sector in Indonesia, dealing with rice production exclusively (Widodo 1986; Erwidodo 1990) as well as with technical efficiency of multiproduct farms (Llewelyn and Williams 1996). Analysis of efficiency in nonagriculture sectors is quite limited. A study by Iswardono and Damarwan (2000) evaluated efficiency in the banking sector in Indonesia between 1991-1996. They found larger banks to be generally more efficient due to economies of scale. Jatmiko (2000) also discussed efficiency in the banking sector in Indonesia, but made no empirical conclusions. Analysis of technical effi- 
ciency in industrial production is very limited, particularly as it relates to firm size.

Several studies have examined the industrial transformation that has occurred in Indonesia in the last twenty years, though without reference to technical efficiency. Hill(1990a) found that productivity growth caused about 60 percent of output growth between 1975 and 1986, with no significant difference occurring between large and small firms. However, during this time period, employment growth was marginally more significant in small firms compared to large firms. In the second part of his analysis, Hill (1990b) specifically discussed the differences between large and small firms, finding that overall, large firms had higher labor productivity and accounted for nearly two-thirds of value added in Indonesia in 1985, but that there were large variations by industry and region, making it difficult to generalize.

In contrast, Aswicahyono et.al.(1996) found that small businesses in Indonesia have performed well in recent years as markets in Indonesia have become increasingly liberalized since the 1980s. Berry, et al. (2001) also reported that small and medium enterprises in Indonesia have shown substantial increases in productivity and seem to be surviving the crisis better than large companies for the most part. They suggest that this may be due to more flexibility since these enterprises rely on formal markets and financing less than large firms as well as technology diffusion through foreign buyers and contractors.

\section{Methodology and Model Development}

Although the use of parametric techniques is common, the use of nonparamet- ric techniques is more limited, despite the fact that nonparametric methodologies can be used in situations where data is more limited and where production technologies are less well understood. There are two nonparametric approaches to production analysis. One is based on the works of Afriat (1972); Hanoch and Rothschild (1972); and Varian (1984). This approach deals with four types of concerns in the neoclassical theory of production: consistency, restriction of form, recoverability, and extrapolation, without maintaining any hypotheses of functional form. This methodology is applied to time series data and has been used in several studies to evaluate technical efficiency in agriculture (e.g., Chavas and Aliber 1993; Chavas and Cox 1988).

Alternatively, Farrell (1957) decomposed efficiency into technical efficiency and allocative efficiency. Färe et al. (1985), introduced a nonparametric method of calculating efficiency, which extended Farrell's approach by relaxing the restrictive assumptions of constant returns to scale and of strong disposability of inputs, the major criticisms of the method.

The model utilized in this study is based on a model originally developed by Grabowski and Pasurka (1987), and is applied to input-output data for seven industries differentiated by firm size. In this approach, a nonparametric production frontier is constructed, with inefficiency being measured by the extent to which a particular size of firm is below the frontier.

This procedure analyzes relative technical efficiency, that is, the production frontier is constructed from the data, and each size of a firm's performance is compared to the frontier to indicate overall technical efficiency of each firm size relative to the others in a given year. This analysis assumes homogeneous inputs, 
potentially a weakness, though the input data used is a monetary value, it seems a reasonable assumption, since differences in inputs across firm size and sector should be accounted for by differences in the value paid for the inputs.

The analysis assumes that $x$ represents a vector of $n$ inputs, $x=\left(\mathrm{x}_{1}, \mathrm{x}_{2}, \ldots, \mathrm{x}_{\mathrm{n}}\right)$

$R^{n}$; that $y$ represents the output vector of $m$ outputs, $y=\left(\mathrm{y}_{1}, \mathrm{y}_{2}, \ldots, \mathrm{y}_{\mathrm{m}}\right) \quad R^{n}{ }_{+}$; and that there are $k$ sizes of firms in the particular industry being evaluated (in this case, three: large, small, and cottage industries). It is also assumed that firms of each size face output prices $p^{k} R^{n}{ }_{+}$, input prices $r^{k} R^{n}{ }_{+}$, target cost $C^{k}>0$, and revenue $R^{k}>0$. The matrix of observed inputs, $X$, of dimension $(\mathrm{n}, \mathrm{k})$ and the matrix of observed outputs, $Y$, of dimension $(\mathrm{m}, \mathrm{k})$ form a transformation set written as:

$\mathrm{T}=\left\{(\mathrm{x}, \mathrm{y}): \mathrm{y}-\mathrm{Yz}, \mathrm{Xz}-\mathrm{x}, \mathrm{z} \quad R_{+}^{\mathrm{k}}\right\} \ldots \ldots . .(1)$

where $z$ is the vector of intensity variables of activity $\left(\mathrm{x}_{\mathrm{i}}, \mathrm{y}_{\mathrm{i}}\right)$. The transformation set corresponds to the total product curve and shows maximum feasible output for a function with constant returns to scale.

For observation $\left(\mathrm{x}_{\mathrm{i}}, \mathrm{y}_{\mathrm{i}}\right)$, overall technical efficiency can be illustrated as follows:

$\theta^{*}\left(\mathrm{x}_{\mathrm{i}}, \mathrm{y}_{\mathrm{i}}\right)=\max \left\{\theta:\left(\mathrm{x}_{\mathrm{i}}, \theta_{\mathrm{i}} \mathrm{y}_{\mathrm{i}}\right)\right.$

$\mathrm{T}\}$

where $\theta$ is the level of inefficiency and $\theta_{i} y_{i}$ is the actual output of the $i$ th firm size. The firm size is technically efficient if $\theta$ equals 1. $\theta$ can be interpreted as the ratio of potential to actual output or alternatively, $1 / \theta$ is the ratio of efficiency relative to the potential frontier output. Technical efficiency can be determined by solving the following linear programming problem:
Max 2

subject to: $x_{11} z_{1}+x_{12} z_{2}+\ldots+x_{1 k} z_{k} \# x_{1 i}$ $x_{21} z_{1}+x_{22} z_{2}+\ldots+x_{2 k} z_{k} \# x_{2 i}$ ........ $\mathrm{x}_{\mathrm{n} 1} \mathrm{z}_{1}+\mathrm{x}_{\mathrm{n} 2} \mathrm{z}_{2}+\ldots+\mathrm{x}_{\mathrm{nk}} \mathrm{z}_{\mathrm{k}} \# \mathrm{x}_{\mathrm{ni}}$ $\mathrm{y}_{11} \mathrm{z}_{1}+\mathrm{y}_{12} \mathrm{z}_{2}+\ldots+\mathrm{y}_{1 \mathrm{k}} \mathrm{z}_{\mathrm{k}}-\mathrm{y}_{1 \mathrm{i}} \theta \cdot 0$ $\mathrm{y}_{21} \mathrm{z}_{1}+\mathrm{y}_{22} \mathrm{z}_{2}+\ldots+\mathrm{y}_{2 \mathrm{k}} \mathrm{z}_{\mathrm{k}}-\mathrm{y}_{2 \mathrm{i}} \theta \cdot 0$ ......... $\mathrm{y}_{\mathrm{m} 1} \mathrm{z}_{1}+\mathrm{y}_{\mathrm{m} 2} \mathrm{z}_{2}+\ldots+\mathrm{y}_{\mathrm{mk}} \mathrm{z}_{\mathrm{k}}-\mathrm{y}_{\mathrm{mi}} \theta \cdot 0$

where there are $n$ input constraints and $m$ output constraints. The output constraint $\left(\mathrm{y}_{\mathrm{i} 1} \mathrm{z}_{1}+\mathrm{y}_{\mathrm{i} 2} \mathrm{z}_{2}+\ldots+\mathrm{y}_{\mathrm{ik}} \mathrm{z}_{\mathrm{k}}\right)$ measures the output level of the (hypothetical) overall technically efficient size of firm. This is the maximum output that can be produced by the $i$ th firm size, given its actual level of inputs. For a single output situation, only one output constraint is needed, as is the case in this analysis.

The term, $y_{m i} \theta$, is the actual production of output $m$ for the $i$ th firm size multiplied by the level of inefficiency, $\theta$. If a particular size of firms are overall technically efficient relative to the other sizes, then $\theta=1$. However, if a particular size is technically inefficient, $\theta>1$. When this is the case, the theoretical maximum output is greater than the actual output of the $i$ th firm size, making that size of firms inefficient relative to the production frontier by a factor of $1 / \theta$.

\section{Data}

Data for this study are from the Central Board of Statistics (BPS) for several years. The BPS data is differentiated by firm size and industry. Three sizes of firms are included: large (greater than $100 \mathrm{em}-$ ployees), small (5-99 employees), and 
household (less than 5 employees). The seven industries analyzed are:

1. Food, beverages, and tobacco (ISIC $=31$ );

2. Textiles, clothing, and leather $(\mathrm{ISIC}=32)$;

3. Wood products and furniture (ISIC $=33$ );

4. Paper, printing and publishing (ISIC=34);

5. Chemicals and plastics (ISIC $=35$ );

6. Nonmetallic mineral products other than petroleum and coal (ISIC $=36$ ); and

7. Fabricated metal products, machinery and equipment (ISIC $=38$ ).

The metallurgical industry (ISIC $=37$ ) and the miscellaneous category (ISIC=39) were not included due to missing data for several years of the analysis period.

Input and output data are given in nominal rupiah for each size of firm for each industry for each year. Since the study analyzes relative efficiency among firm sizes for each year within each industry, it is not necessary to use real values, eliminating the need for transforming these nominal values.

The data used for the primary portion of the analysis are for 1991 to 1997. Prior to 1991 , data were collected and reported only for large industry size, not for small or household size. Exceptions to this were the years 1974/75, 1979, and 1986, when data were collected for all sizes for each industry, but since the data are not continuous and since there were several differences in how the data was collected during these earlier years, these three years are not included. During the economic crisis (1998 and following), data collection was limited to large industries only, making comparisons during these years not possible.

\section{Empirical Analysis and Results}

Using the linear programming methodology outlined earlier, nonparametric analysis of relative technical efficiency is performed for each firm size in each industry for each of the six years of the study. The linear program (using Equations 3 ) is solved to provide the values of $\theta$ for each firm size for each industry. The analysis is conducted using Generalized Algebraic Modeling System (GAMS) software, which utilizes the MINOS solver (Brooke et al. 1988).

The relative technical efficiencies for each size of firm for each year are reported for each industry. The average overall efficiency is calculated by dividing $1 / \theta$ for each region to obtain the overall efficiency level for that particular firm size. A firm size that is relatively technically efficient has an efficiency of 100 percent. In each year, there will be at least one observation, which is 100 percent relatively efficient (the most efficient for that year).

Results of the efficiency analysis by industry are summarized in Table 1 . This analysis compares the relative efficiency of large, small, and household firms for each year by sector as well as the average relative technical efficiency for each size of firm for the seven-year analysis period.

For the first category, Food, Beverage and Tobacco, the large size firms are relatively more efficient for each year, making the average relative technical efficiency for large firms 100 percent. Household firms are, on average, 12 percent less efficient than the large firms for this sector and small firms are the least efficient in this category, with an average of only 79.8 percent average efficiency. Such a result 
Llewelyn \& Sutrisno-Does Size Matter?

Table 1. Relative Technical Efficiency for Various Indonesian Industries, By Firm Size 1991-1997

\begin{tabular}{|c|c|c|c|}
\hline \multicolumn{4}{|c|}{ Food, Beverages, and Tobacco $($ ISIC $=31)$} \\
\hline$\underline{\text { Year }}$ & $\underline{\text { Large }}$ & $\underline{\text { Small }}$ & Household \\
\hline 1991 & $100.0 \%$ & $75.7 \%$ & $86.6 \%$ \\
\hline 1992 & $100.0 \%$ & $75.4 \%$ & $8 \$ .0 \%$ \\
\hline 1993 & $100.0 \%$ & $86.9 \%$ & $94.7 \%$ \\
\hline 1994 & $100.0 \%$ & $81.8 \%$ & $91.3 \%$ \\
\hline 1995 & $100.0 \%$ & $77.5 \%$ & $84.2 \%$ \\
\hline 1996 & $100.0 \%$ & $82.6 \%$ & $89.7 \%$ \\
\hline 1997 & $100.0 \%$ & $78.8 \%$ & $85.5 \%$ \\
\hline Average & $100.0 \%$ & $79.8 \%$ & $88.0 \%$ \\
\hline Std. Deviation & 0.000 & 0.042 & 0.040 \\
\hline Maximum & $100.0 \%$ & $86.9 \%$ & $94.7 \%$ \\
\hline Minimum & $100.0 \%$ & $75.4 \%$ & $84.0 \%$ \\
\hline \multicolumn{4}{|c|}{ Textiles, Clothing, and Leather (ISIC=32) } \\
\hline Year & $\underline{\text { Large }}$ & $\underline{\text { Small }}$ & Household \\
\hline 1991 & $80.8 \%$ & $100.0 \%$ & $81.4 \%$ \\
\hline 1992 & $87.4 \%$ & $100.0 \%$ & $92.6 \%$ \\
\hline 1993 & $99.2 \%$ & $98.8 \%$ & $100.0 \%$ \\
\hline 1994 & $97.9 \%$ & $81.0 \%$ & $100.0 \%$ \\
\hline 1995 & $98.3 \%$ & $92.4 \%$ & $100.0 \%$ \\
\hline 1996 & $100.0 \%$ & $96.9 \%$ & $100.0 \%$ \\
\hline 1997 & $96.4 \%$ & $96.9 \%$ & $100.0 \%$ \\
\hline Average & $94.3 \%$ & $95.1 \%$ & $96.3 \%$ \\
\hline Std. Deviation & 0.073 & 0.068 & 0.071 \\
\hline Maximum & $100.0 \%$ & $100.0 \%$ & $100.0 \%$ \\
\hline Minimum & $80.8 \%$ & $81.0 \%$ & $81.4 \%$ \\
\hline \multicolumn{4}{|c|}{ Wood products and furniture (ISIC $=\mathbf{3 3}$ ) } \\
\hline$\underline{\text { Year }}$ & $\underline{\text { Large }}$ & $\underline{\text { Small }}$ & Household \\
\hline 1991 & $63.1 \%$ & $73.7 \%$ & $100.0 \%$ \\
\hline 1992 & $74.6 \%$ & $80.1 \%$ & $100.0 \%$ \\
\hline 1993 & $76.5 \%$ & $84.2 \%$ & $100.0 \%$ \\
\hline 1994 & $80.6 \%$ & $96.8 \%$ & $100.0 \%$ \\
\hline 1995 & $82.5 \%$ & $91.2 \%$ & $100.0 \%$ \\
\hline 1996 & $80.6 \%$ & $91.2 \%$ & $100.0 \%$ \\
\hline 1997 & $82.2 \%$ & $91.2 \%$ & $100.0 \%$ \\
\hline Average & $77.2 \%$ & $86.9 \%$ & $100.0 \%$ \\
\hline Std. Deviation & 0.069 & 0.080 & 0.000 \\
\hline Maximum & $82.5 \%$ & $96.8 \%$ & $100.0 \%$ \\
\hline Minimum & $63.1 \%$ & $73.7 \%$ & $100.0 \%$ \\
\hline
\end{tabular}


Table 1. (continued)

Paper, printing and publishing (ISIC $=34$ )

$\underline{\text { Year }}$

1991

1992

1993

1994

1995

1996

1997

Average

Std. Deviation

Maximum

Minimum

Chemicals and plastics (ISIC $=35$ )

\section{Year}

1991

1992

1993

1994

1995

1996

1997

Average

Std. Deviation

Maximum

Minimum
Large

$59.5 \%$

$65.8 \%$

$69.3 \%$

$68.2 \%$

$87.2 \%$

$88.5 \%$

$100.0 \%$

$76.9 \%$

0.149

$100.0 \%$

$59.5 \%$

Large

$88.9 \%$

$91.6 \%$

$82.9 \%$

$92.7 \%$

$68.6 \%$

$68.9 \%$

$68.1 \%$

$80.2 \%$

0.114

$92.7 \%$

$68.1 \%$

\begin{tabular}{c}
$\underline{\text { Small }}$ \\
$100.0 \%$ \\
$100.0 \%$ \\
$85.6 \%$ \\
$91.3 \%$ \\
$76.6 \%$ \\
$76.6 \%$ \\
$76.0 \%$ \\
$86.6 \%$ \\
0.107 \\
$100.0 \%$ \\
$76.0 \%$ \\
\hline
\end{tabular}

Household

$86.6 \%$

$84.0 \%$

$100.0 \%$

$100.0 \%$

$100.0 \%$

$100.0 \%$

$99.8 \%$

$95.8 \%$

0.072

$100.0 \%$

$84.0 \%$

$\begin{array}{cc}\text { Small } & \text { Household } \\ 89.5 \% & 100.0 \% \\ 91.6 \% & 100.0 \% \\ 82.2 \% & 100.0 \% \\ 100.0 \% & 91.8 \% \\ 65.5 \% & 100.0 \% \\ 65.6 \% & 100.0 \% \\ 65.1 \% & 100.0 \% \\ 79.9 \% & 98.8 \% \\ 0.145 & 0.031 \\ 100.0 \% & 100.0 \% \\ 65.1 \% & 91.8 \%\end{array}$

Non-metallic mineral products other than petroleum and coal (ISIC $=36$ )

Year

1991

1992

1993

1994

1995

1996

1997

Average

Std. Deviation

Maximum

Minimum
Large

$78.5 \%$

$77.8 \%$

$77.6 \%$

$80.5 \%$

$71.8 \%$

$73.9 \%$

$77.1 \%$

$76.7 \%$

0.029

$80.5 \%$

$71.8 \%$
Small

93.6\%

$94.3 \%$

$95.2 \%$

$89.8 \%$

$91.3 \%$

$91.3 \%$

$91.2 \%$

$92.4 \%$

0.020

$95.2 \%$

$89.8 \%$
Household

$100.0 \%$

$100.0 \%$

$100.0 \%$

$100.0 \%$

$100.0 \%$

$100.0 \%$

$100.0 \%$

$100.0 \%$

0.000

$100.0 \%$

$100.0 \%$

304 
Llewelyn \& Sutrisno—Does Size Matter?

Table 1. (continued)

\begin{tabular}{|c|c|c|c|}
\hline \multicolumn{4}{|c|}{ Fabricated metal products, machinery and equipment $($ ISIC $=38)$} \\
\hline$\underline{\text { Year }}$ & $\underline{\text { Large }}$ & Small & Household \\
\hline 1991 & $87.9 \%$ & $100.0 \%$ & $93.2 \%$ \\
\hline 1992 & $98.9 \%$ & $100.0 \%$ & $90.3 \%$ \\
\hline 1993 & $91.9 \%$ & $100.0 \%$ & $86.1 \%$ \\
\hline 1994 & $86.1 \%$ & $100.0 \%$ & $92.5 \%$ \\
\hline 1995 & $91.1 \%$ & $99.6 \%$ & $100.0 \%$ \\
\hline 1996 & $93.8 \%$ & $99.7 \%$ & $100.0 \%$ \\
\hline 1997 & $95.8 \%$ & $99.1 \%$ & $100.0 \%$ \\
\hline Average & $92.2 \%$ & $99.8 \%$ & $94.6 \%$ \\
\hline Std. Deviation & 0.044 & 0.003 & 0.055 \\
\hline Maximum & $98.9 \%$ & $100.0 \%$ & $100.0 \%$ \\
\hline Minimum & $86.1 \%$ & $99.1 \%$ & $86.1 \%$ \\
\hline \multicolumn{4}{|l|}{ All Industries } \\
\hline Year & $\underline{\text { Large }}$ & Small & Household \\
\hline 1991 & $90.7 \%$ & $96.1 \%$ & $100.0 \%$ \\
\hline 1992 & $98.8 \%$ & $96.5 \%$ & $100.0 \%$ \\
\hline 1993 & $98.0 \%$ & $93.9 \%$ & $100.0 \%$ \\
\hline 1994 & $98.8 \%$ & $89.8 \%$ & $100.0 \%$ \\
\hline 1995 & $99.8 \%$ & $92.4 \%$ & $100.0 \%$ \\
\hline 1996 & $99.4 \%$ & $92.1 \%$ & $100.0 \%$ \\
\hline 1997 & $100.0 \%$ & $91.4 \%$ & $98.6 \%$ \\
\hline Average & $97.9 \%$ & $93.2 \%$ & $99.8 \%$ \\
\hline Std. Deviation & 0.032 & 0.025 & 0.005 \\
\hline Maximum & $100.0 \%$ & $96.5 \%$ & $100.0 \%$ \\
\hline Minimum & $90.7 \%$ & $89.8 \%$ & $98.6 \%$ \\
\hline
\end{tabular}

may be due to the influence of the cigarette industry, which is dominated by five or six large firms, all of which have performed well both pre- and post-crisis.

All firms of any size are relatively efficient for the second category, Textiles, Clothing and Leather, with household firms being most efficient (96.3\% average efficiency) and large firms the least (94.3\%), with an average difference of only two percent in relative efficiency over the seven-year period. This may be due to relative homogeneity of production processes in the textile, clothing and leather sector compared to other industries.
Household firms are also relatively more efficient for the category of Wood Products and Furniture, but in this case, much more than for textiles. Household firms are 100 percent relatively efficient, with small firms being next in efficiency for this sector with $86.9 \%$ relative efficiency and large firms having the lowest efficiency $(77.2 \%)$. Many furniture production, particularly on Java, occurs in family owned businesses and may be the most efficient type of operation for this particular sector.

For the next three sectors, Paper, Printing, and Publishing; Chemicals and 
Plastics; and Nonmetallic Mineral Products, household firms are relatively more efficient than the other two sizes of firms, with relative efficiencies of 95.8 percent, 98.8 percent and 100 percent, respectively. Large businesses are relatively more efficient than small firms for the chemical industry, but only marginally so, 80.2 percent versus 79.9 percent average relative efficiency. Small businesses are relatively more efficient than large businesses for the other two sectors. With regard to the paper industry, several large firms in this sector (Asia Pulp and Paper, for example) have experienced financial and production difficulties, perhaps an indication of relative inefficiency and not just a result of the economic crisis.

The relatively high efficiency of household firms for all of these sectors may indicate the reason for the existence of a "duel" economy in many production sectors (noted by Hill 1999), where cottage industries and large firms are both present in the market. Large firms may achieve some economies of scale, but the relative technical efficiency of household firms may allow them to continue to remain in the market.

The final sector is Fabricated Metal Products, Machinery and Equipment. Results show that all sizes of firms are relatively efficient, but small firms are most efficient in this sector (99.8 percent). However, household firms and large businesses closely follow with average relative efficiencies of 94.6 percent and 92.2 percent, respectively, making it difficult to make a definite conclusion. The relatively high efficiencies of all sizes of firms may be due to homogeneity of inputs, particularly labor and raw materials in this industry.

When all input and output data are aggregated for all industries and analysis is done by size of firm, the results (also in
Table 1) show that overall, household firms are relatively more efficient ( 99.8 percent) than the other two sizes of firms. Large firms (97.9 percent) are found to be relatively more efficient than small firms ( 93.2 percent), though this is not a large difference. The very highly aggregated data for this analysis tends to cause the relative differences between firm sizes to be less pronounced than for the individual sectors.

It is apparent that the type of industry affects the results. Household firms are more efficient for five of the seven sectors evaluated with large firms more efficient in one sector and small firms the most efficient in the remaining sector. In two sectors (Textiles, Clothing and Leather; and Fabricated Metal Products, Machinery and Equipment), all sizes of firms had average relative efficiency of more than 90 percent. Large firms were relatively more efficient for the Food, Beverage, and Tobacco sector, perhaps due to the role of large cigarette companies. Small firms were relatively more efficient for the $\mathrm{Fab}$ ricated Metal Products sector, but there was not much difference with the other firms size.

In addition to the efficiency analysis by firm size, a second analysis evaluated the relative efficiency of each sector for each size of firm. The results are reported in Table 2. For all firms size, the Nonmetallic Mineral Products Other Than Petroleum and Coal sector is found to be the most efficient sector based on average relative efficiency. This is a relatively small sector, based on value-added (accounting for only about 6.4 percent of total valueadded in manufacturing), but is relatively efficient for all sizes of firms compared to the other sectors in the analysis. This may be due to the fact that this sector has a long history of operation in Indonesia, creating 
Llewelyn \& Sutrisno-Does Size Matter?

Table 2. Cross-Sector Analysis By Firm Size

\begin{tabular}{|c|c|c|c|c|c|c|c|}
\hline Year & 31 & 32 & 33 & 34 & 35 & 36 & 38 \\
\hline 1991 & $100.0 \%$ & $82.4 \%$ & $87.6 \%$ & $92.3 \%$ & $86.5 \%$ & $97.8 \%$ & $84.7 \%$ \\
\hline 1992 & $100.0 \%$ & $85.3 \%$ & $92.5 \%$ & $92.5 \%$ & $84.6 \%$ & $99.7 \%$ & $98.9 \%$ \\
\hline 1993 & $85.2 \%$ & $89.1 \%$ & $85.8 \%$ & $90.8 \%$ & $87.0 \%$ & $100.0 \%$ & $95.1 \%$ \\
\hline 1994 & $91.2 \%$ & $94.4 \%$ & $86.0 \%$ & $91.5 \%$ & $85.6 \%$ & $100.0 \%$ & $97.1 \%$ \\
\hline 1995 & $100.0 \%$ & $92.8 \%$ & $92.3 \%$ & $92.6 \%$ & $88.3 \%$ & $99.8 \%$ & $95.5 \%$ \\
\hline 1996 & $91.6 \%$ & $92.1 \%$ & $88.0 \%$ & $91.7 \%$ & $87.0 \%$ & $100.0 \%$ & $96.0 \%$ \\
\hline 1997 & $91.8 \%$ & $85.0 \%$ & $85.9 \%$ & $99.0 \%$ & $82.4 \%$ & $100.0 \%$ & $93.9 \%$ \\
\hline Average & $94.2 \%$ & $88.7 \%$ & $88.3 \%$ & $92.9 \%$ & $85.9 \%$ & $99.6 \%$ & $94.5 \%$ \\
\hline Std. Deviation & 0.058 & 0.046 & 0.029 & 0.028 & 0.020 & 0.008 & 0.046 \\
\hline Maximum & $100.0 \%$ & $94.4 \%$ & $92.5 \%$ & $99.0 \%$ & $88.3 \%$ & $100.0 \%$ & $98.9 \%$ \\
\hline Minimum & $85.2 \%$ & $82.4 \%$ & $85.8 \%$ & $90.8 \%$ & $82.4 \%$ & $97.8 \%$ & $84.7 \%$ \\
\hline \multicolumn{8}{|l|}{ Small Firms } \\
\hline$\underline{\text { Year }}$ & 31 & 32 & 33 & 34 & 35 & 36 & 38 \\
\hline 1991 & $48.8 \%$ & $71.0 \%$ & $65.9 \%$ & $100.0 \%$ & $59.3 \%$ & $75.1 \%$ & $62.4 \%$ \\
\hline 1992 & $54.5 \%$ & $70.6 \%$ & $71.7 \%$ & $100.0 \%$ & $63.8 \%$ & $86.6 \%$ & $72.4 \%$ \\
\hline 1993 & $60.1 \%$ & $72.1 \%$ & $76.7 \%$ & $83.5 \%$ & $71.1 \%$ & $100.0 \%$ & $84.0 \%$ \\
\hline 1994 & $61.1 \%$ & $69.7 \%$ & $84.7 \%$ & $100.0 \%$ & $75.1 \%$ & $91.6 \%$ & $93.1 \%$ \\
\hline 1995 & $61.1 \%$ & $72.1 \%$ & $80.4 \%$ & $68.7 \%$ & $68.1 \%$ & $100.0 \%$ & $82.4 \%$ \\
\hline 1996 & $61.1 \%$ & $72.2 \%$ & $80.5 \%$ & $64.3 \%$ & $67.8 \%$ & $100.0 \%$ & $93.2 \%$ \\
\hline 1997 & $61.2 \%$ & $72.2 \%$ & $80.5 \%$ & $64.1 \%$ & $67.9 \%$ & $100.0 \%$ & $82.3 \%$ \\
\hline Average & $58.3 \%$ & $71.4 \%$ & $77.2 \%$ & $82.9 \%$ & $67.6 \%$ & $93.3 \%$ & $81.4 \%$ \\
\hline Std. Deviation & 0.048 & 0.010 & 0.064 & 0.172 & 0.050 & 0.097 & 0.110 \\
\hline Maximum & $61.2 \%$ & $72.2 \%$ & $84.7 \%$ & $100.0 \%$ & $75.1 \%$ & $100.0 \%$ & $93.2 \%$ \\
\hline Minimum & $48.8 \%$ & $69.7 \%$ & $65.9 \%$ & $64.1 \%$ & $59.3 \%$ & $75.1 \%$ & $62.4 \%$ \\
\hline \multicolumn{8}{|c|}{ Household Firms } \\
\hline Year & 31 & 32 & 33 & 34 & 35 & 36 & 38 \\
\hline 1991 & $62.3 \%$ & $64.6 \%$ & $100.0 \%$ & $84.2 \%$ & $93.5 \%$ & $89.8 \%$ & $64.8 \%$ \\
\hline 1992 & $66.5 \%$ & $71.6 \%$ & $98.1 \%$ & $98.1 \%$ & $87.1 \%$ & $100.0 \%$ & $71.5 \%$ \\
\hline 1993 & $61.7 \%$ & $68.8 \%$ & $85.8 \%$ & $100.0 \%$ & $80.8 \%$ & $98.8 \%$ & $68.2 \%$ \\
\hline 1994 & $62.0 \%$ & $71.8 \%$ & $79.5 \%$ & $100.0 \%$ & $63.3 \%$ & $92.4 \%$ & $77.5 \%$ \\
\hline 1995 & $60.5 \%$ & $67.9 \%$ & $80.5 \%$ & $76.5 \%$ & $94.3 \%$ & $100.0 \%$ & $75.6 \%$ \\
\hline 1996 & $60.5 \%$ & $68.0 \%$ & $80.6 \%$ & $76.0 \%$ & $94.7 \%$ & $100.0 \%$ & $75.5 \%$ \\
\hline 1997 & $60.6 \%$ & $68.1 \%$ & $80.6 \%$ & $76.3 \%$ & $94.6 \%$ & $100.0 \%$ & $75.6 \%$ \\
\hline Average & $62.0 \%$ & $68.7 \%$ & $86.4 \%$ & $87.3 \%$ & $86.9 \%$ & $97.3 \%$ & $72.7 \%$ \\
\hline Std. Deviation & 0.021 & 0.025 & 0.089 & 0.116 & 0.117 & 0.043 & 0.047 \\
\hline Maximum & $66.5 \%$ & $71.8 \%$ & $100.0 \%$ & $100.0 \%$ & $94.7 \%$ & $100.0 \%$ & $77.5 \%$ \\
\hline Minimum & $60.5 \%$ & $64.6 \%$ & $79.5 \%$ & $76.0 \%$ & $63.3 \%$ & $89.8 \%$ & $64.8 \%$ \\
\hline
\end{tabular}


Table 2. (continued)

\begin{tabular}{|c|c|c|c|c|c|c|c|}
\hline \multicolumn{8}{|l|}{ All Firms } \\
\hline Year & 31 & 32 & 33 & 34 & 35 & 36 & 38 \\
\hline 1991 & $95.4 \%$ & $83.5 \%$ & $91.2 \%$ & $92.1 \%$ & $85.8 \%$ & $100.0 \%$ & $84.3 \%$ \\
\hline 1992 & $94.0 \%$ & $83.8 \%$ & $92.8 \%$ & $90.3 \%$ & $79.6 \%$ & $100.0 \%$ & $96.1 \%$ \\
\hline 1993 & $90.7 \%$ & $84.0 \%$ & $93.2 \%$ & $92.5 \%$ & $82.2 \%$ & $100.0 \%$ & $93.7 \%$ \\
\hline 1994 & $84.8 \%$ & $90.7 \%$ & $85.9 \%$ & $89.0 \%$ & $82.9 \%$ & $100.0 \%$ & $94.1 \%$ \\
\hline 1995 & $90.4 \%$ & $82.9 \%$ & $89.5 \%$ & $87.4 \%$ & $83.6 \%$ & $100.0 \%$ & $90.5 \%$ \\
\hline 1996 & $85.0 \%$ & $87.7 \%$ & $86.3 \%$ & $87.3 \%$ & $83.2 \%$ & $100.0 \%$ & $91.7 \%$ \\
\hline 1997 & $85.1 \%$ & $82.0 \%$ & $84.7 \%$ & $94.6 \%$ & $79.5 \%$ & $100.0 \%$ & $90.6 \%$ \\
\hline Average & $89.3 \%$ & $85.0 \%$ & $89.1 \%$ & $90.5 \%$ & $82.4 \%$ & $100.0 \%$ & $91.6 \%$ \\
\hline Standard Dev & on0.044 & 0.031 & 0.035 & 0.027 & 0.023 & 0.000 & 0.038 \\
\hline Maximum & $95.4 \%$ & $90.7 \%$ & $93.2 \%$ & $94.6 \%$ & $85.8 \%$ & $100.0 \%$ & $96.1 \%$ \\
\hline Minimum & $84.8 \%$ & $82.0 \%$ & $84.7 \%$ & $87.3 \%$ & $79.5 \%$ & $100.0 \%$ & $84.3 \%$ \\
\hline
\end{tabular}

high technical efficiency through having developed the production process thoroughly for all sizes of firms.

For large firms, three other sectors showed relative efficiencies which were more than 90 percent, including Food, Beverages, and Tobacco; Paper, Printing and Publishing; and Fabricated Metal Products, Machinery and Equipment. The other sectors were all having more than 85 percent relative efficiency for the large firm analysis. This shows that all large firms in each industry are not far apart in their relative efficiency from each other.

A wider range of results was found for the small firms. Only two other sectors showed average efficiencies more than 80 percent (Paper, Printing and Publishing, and Fabricated Metal Products, Machinery and Equipment). The others ranged down to Food, Beverage, and Tobacco with an average relative efficiency of only 58.3 percent in this analysis. Low efficiency for the food industry may be due to low levels of technology and relatively high labor inputs used in small firms

The analysis of each sector for the household size firms showed a similar result with the exception of Fabricated
Metal Products, Machinery and Equipment, which had much lower average efficiency relative to the other sectors, compared with the other firms size. The Food, Beverage, and Tobacco sector was again the lowest for the household analysis. Again, this may be due to overuse of labor, particularly household labor, in operations of food and beverage establishments.

When all sizes of firms were aggregated and the sectors were evaluated based on total input and output irregardless of firm size, the Nonmetallic Mineral Products sector is again found to be the most efficient sector, followed by Fabricated Metal Products, Machinery and Equipment, then Paper, Printing, and Publishing and then Food, Beverage, and Tobacco. The lowest efficiency is found in the Chemical and Plastics sector, due in part to the high cost of imported raw materials perhaps as well as the relatively low levels of technology in this sector.

The results suggest policy implementations for each industry. As a general rule, the relative efficiency of small and household firms suggests that such firms are already able to compete with large firms and do not need special dispensations or 
advantages given to them. The relative inefficiency of large firms suggests that the government should discontinue special favors and rules for large companies with political ties and allow the market to determine market structure in each industry.

Specifically, there are several policy suggestions, which can be made based on these results. First, due to the relative efficiency of the large companies in the Food, Beverages, and Tobacco sector, the heavy taxation of this sector should be reduced. The tobacco excise tax in particular is quite burdensome to an industry, which has been found to be efficient, and instead of taxing (and thus reducing) efficiency, such efficiency should be rewarded with further incentive in the form of lower taxes. The sales tax on food and beverage sales should also be reconsidered.

The relative efficiency of all sizes of firms in the Textiles, Clothing and Leather industry suggests that these firms do not need further incentives. Export incentives as well as import barriers, which currently are enjoyed by this sector should be reconsidered and withdrawn in an orderly fashion. This will stimulate further efficiency gains through competition, particularly as competition from Chinese firms worldwide requires this industry to be increasingly competitive.

Given the relative efficiency of small and household firms for the Wood Products and Furniture sector, a major reform, which could be made, is providing access to raw materials in smaller lots. Currently, forest products are sold in relatively large lots, requiring large investment. Increasing access for smaller firms to the raw materials can allow these relatively efficient firms to become even more efficient.

In the Paper, Printing and Publishing industry, one major policy change needed is related to the enforcement of copyright laws, so that small companies which invest in a large publishing project will be able to obtain a return on that investment. Currently, many books published do not sell well due to the fact that many are photocopied after publication, both by individuals as well as institutions. Enforcing copyright laws will ensure that small (as well as large) companies will be able to continue publishing qualified material. In addition, further easing of press regulation and permits will allow small firms to profit from their relative technical efficiency.

Deregulation of import restrictions seems to be a key policy needed for the Chemicals and Plastics industry. Since household firms are most efficient, these small firms can contribute significantly to the growth of this sector. However, because much of the raw material needed in this industry is imported, household firms find it more difficult to obtain the necessary materials than larger firms, which were found to be technically less efficient. To level the playing field, a decrease in import restrictions would allow smaller firms to have more access to materials while at the same time create competition from abroad, which would push larger firms to become more efficient.

A likely multiplier effect in the Nonmetallic Minerals sector should be sufficient motivation for lower taxes on companies in this sector. Since the products produced by this industry are mostly intermediate goods, which are used by other companies to produce final goods, the incentive of lower taxes in this sector would allow lower prices of the intermediate goods produced, stimulating growth in other sectors as well.

The final sector, Fabricated Metal Products, Machinery and Equipment, is 
already relatively efficient for all sizes of firms, implying only little needs to be done by the government. The previous suggestions of lowering taxes for this sector and decreasing import restrictions to stimulate further competition and increase efficiency can also be applied here.

\section{Summary and Conclusions}

Nonparametric analysis of technical efficiency for various firm sizes in different industries in Indonesia is developed using a model based on techniques developed and used by Grabowski and Pasurka (1987). This procedure allows the relative technical efficiency for each size of firm to be determined. This methodology also does not require restrictions or assumptions regarding functional form to be placed on the data. Efficiencies are estimated using linear programming techniques.

The model is applied to aggregated BPS data from 1991 to 1997 . The data used are aggregate input and output data by sector (using seven manufacturing sectors) and by firm size (large (more than 100 employees), small (5-99 employees), and household (less than 5 employees).

Though the empirical application utilizes highly aggregated data, several interesting conclusions can be drawn. First, large firms are not necessarily inefficient, though this study finds the household size of firms to be most efficient relative to the other sizes for five of the seven sectors analyzed. Large firms are relatively more efficient than all other sizes for the Food, Beverage, and Tobacco sector, perhaps due to the dominant role of cigarette companies in this sector in Indonesia.

Small companies are relatively less efficient than household firms in all but one case, but relatively more efficient than large firms in five of seven sectors (the exceptions being Food, Beverage, and Tobacco as well as Chemicals and Plastics). The high efficiency of household firms may show the reason for the continuing duel economy in Indonesia where large and small companies exist in the same industry with large companies able to obtain economies of scale, but small firms surviving due to efficiency advantages.

When each sector is analyzed for each firm size, the Nonmetallic Mineral Products Other Than Petroleum and Coal sector is most efficient for all sizes of firms. Other sectors, which show relatively high average efficiency, include Food, Beverages, and Tobacco; Paper, Printing and Publishing; and Fabricated Metal Products, Machinery and Equipment. The least efficient sector is the Chemical and Plastics industry.

The results make it difficult to generalize regarding what type of firm size, and more generally, what type of industrial structure, is desirable. This suggests that industry structure should depend on market processes, which determine the relative importance of each size category within a particular industry.

The results indicate that small and household industries are generally efficient, implying that they do not need specific government intervention or assistance. Since they are already relatively efficient, even at a time when government policies were generally slanted toward the large firms (during 1991-1997), these smaller firms should be able to compete well in a situation where market forces are allowed to operate.

The Indonesian government tried various interventions in period before the crisis to develop small industry, including subsidized credit, training programs, subsidized inputs, marketing assistance, and advisory extension workers. However, the 
results of this study suggest that such programs are unnecessary, given the relative efficiency of small firms, and that government's role should be to promote and facilitate a stable business environment with such infrastructure as is necessary for the private sector to function.

Analysis of each sector indicates that the chemical and textile sectors are relatively inefficient for all sizes of firms, perhaps an indication that further trade protection of these sectors is unjustified, including export promotion programs and continued import barriers for textiles and clothing.

General policy implications include lower taxes for efficient sectors and the consequent lowering of import barriers and other protections to further stimulate competition and efficiency. Providing small companies with greater access to raw materials, either through changing procurement procedures or through deregulating import procedures, will provide opportunities for small and household firms, which are efficient, to compete effectively with large firms, even if large firms have the advantage of economies of scale. In most cases, the government should reduce its role in these industries and allow market forces to determine the appropriate industry structure.

This type of analysis has as its strength, the ability to use limited inputoutput data and analyze a small number of sizes of firms, using aggregated data, without requiring a production function to be specified. Thus, various firms size and industries, with highly varied production technologies and processes can be compared to each other.

The limitations of this study should be noted. As is often the case, the data represent the greatest weakness. The data are for only seven years, and are for three sizes of firms, requiring the use of aggregated data. A study comparing individual firms in each sector, with further analysis of characteristics of efficient firms could be useful, since there are quite possible differences in efficiency levels between firms of the same size in a given industry. Measurement errors in the data, particularly for the small and household data could significantly affect the results as well.

\section{References}

Afriat, S. N. 1972. Efficiency estimation of production functions. International Economic Review 13: 568-598.

Aswicahyono, H. H., K. Bird, and H. Hill. 1996. What happens to industrial structure when countries liberalize? Indonesia since the mid 1980's. Journal of Development Studies 32 (3): 340-363.

Berry, A., E. Rodriguez, and H. Sandee. 2001. Small and medium enterprise dynamics in Indonesia. Bulletin of Indonesian Economic Studies 37 (3): 363-384.

Brooke, A., D. Kendrick, and A. Meeraus. 1988. Generalized algebraic modeling system (GAMS). International Bankfor Reconstruction and Development/The World Bank. 
Gadjah Mada International Journal of Business, September 2002, Vol. 4, No. 3

Byerlee, D. 1987. Maintaining the Momentum in Post-Green Revolution Agriculture: A Micro-Level Perspective from Asia. East Lansing Michigan: Department of Agricultural Economics, Michigan State University.

Central Bureau of Statistics (BPS). 1994. Statistik Indonesia 1993. Jakarta.

. 1995. Statistik Indonesia 1994. Jakarta.

. 1996. Statistik Indonesia 1995. Jakarta.

. 1997. Statistik Indonesia 1996. Jakarta.

1998. Statistik Indonesia 1997. Jakarta.

Chavas, J. P., and M. Aliber. 1993. An analysis of economic efficiency in agriculture: A nonparametric approach. Journal of Agricultural and Resource Economics 18 (1): 116.

Chavas, J. P., and T. L. Cox. 1988. A nonparametric analysis of agricultural technology. American Journal of Agricultural Economics 70 (2): 303-310.

Erwidodo.1990. Panel data analysis on farm-level efficiency, input demand and output supply of rice farming in West Java, Indonesia. Ph.D. Dissertation. Michigan State University.

Farrell, M. J. 1957. The measurement of production efficiency. Journal of the Royal Statistical Society (2) (Series A): 252-67.

Färe, R., S. Grosskopf, and C.A.K. Lovell. 1985. The Measurement of Efficiency of Production. Boston: Kluwer-Nijhoff Publishing.

Featherstone, A. M., M. R. Langemejer, and M. Ismet. 1977. A nonparametric analysis of efficiency for a sample of Kansas beef cow farms. Journal of Agriculture and Applied Economics 29 (1): 175-184.

Grabowski, R., and C. Pasurka. 1987. The relative technical efficiency of Northern and Southern U.S. farms in 1860. Southern Economic Journal 32: 598-614.

Hanoch, G., and M. Rothschild. 1972. Testing the assumptions of production theory: A nonparametric approach. Journal of Political Economy 80: 256-275.

Hill, H. 1990a. Indonesia's industrial transformation: Part I. Bulletin of Indonesian Economic Studies 26 (2): 79-120.

1990b. Indonesia's industrial transformation: Part II. Bulletin of Indonesian Economic Studies 26 (3): 75-110.

1999. Indonesia's microeconomic policy challenges: Industry policy, competition policy, and small-medium enterprises. The Indonesian Quarterly XXVII (1): 22-33.

Iswardono, S. P., and Darmawan. 2000. Analisis efisiensi industri perbankan di Indonesia. Jurnal Ekonomi dan Bisnis Indonesia. 15(1): 1-13.

312 
Llewelyn \& Sutrisno—Does Size Matter?

Jatmiko, P. B. 2000. Paradigma structure, conduct and performance versus hipotesis efisiensi: Manakah yang mencerminkan industri perbankan Indonesia? Jurnal Ekonomi dan Bisnis Indonesia 15 (3): 339-348.

Jakarta Post. 2001. Government policies only benefit big businesses: MPR speaker www.thejakartapost.com/detaillatestnews.asp?fileid $=20011006155640$ (6 October 2001).

Llewelyn, R.V. 1997. Evaluating regional technical efficiency of food crop production. In Indonesia using nonparametric analysis: Ekonomi dan Keuangan Indonesia. XLV (4): 617-630.

Llewelyn, R.V., and J.R. Williams. 1996. Non-parametric analysis of technical, pure technical and scale efficiency for food crop production in East Java, Indonesia. Agricultural Economics 15 (2): 113-126.

Varian, H. 1984. The nonparametric approach to production analysis. Econometrica 52: 579-597.

Widodo, S. 1986. An econometric study of production efficiency among rice farmers in irrigated lowland villages in Java, Indonesia. M.S. Thesis. Tokyo University of Agriculture. 